\title{
WIELOKULTUROWOŚĆ JAKO CZYNNIK ZRÓWNOWAŻONEGO I INTELIGENTNEGO ROZWOJU POLSKI
}

\begin{abstract}
Streszczenie
W referacie autor próbuje odpowiedzieć na pytanie, jaka jest rola (znaczenie) wielokulturowości jako realnego czynnika zróżnicowanego i inteligentnego rozwoju Polski.

Natomiast wielokulturowość jest formą odpowiedzi na inne pytanie, jaka jest i na czym ma polegać demokracja w sferze kulturowej.

Najogólniej wpływ wielokulturowości na zrównoważony i inteligentny rozwój Polski wiąże się z oczekiwanym jej wpływem na kształtowanie się nowego ładu społeczno-kulturowego w społeczeństwie. Generalnie wielokulturowość sprzyja integracji społeczeństwa zróżnicowanego kulturowo. Służy nowym formom pożądanej spójności społecznej jako koniecznego czynnika wzrostu gospodarczego i społecznego rozwoju w warunkach ponowoczesnej gospodarki. Usuwa ze stosunków międzyludzkich różne formy predestynacji kulturowej, dowartościowuje kultury mniejszościowe, co powoduje ich włączanie, a więc umacnia przez to siłę ekonomiczną społeczeństwa. Stwarza lepsze warunki do wykorzystania zróżnicowanego kulturowo kapitału: ludzkiego, społecznego i kulturowego. W przekonaniu autora, obecnie Polska znajduje się na etapie rozwiązywania wielu dylematów związanych z ewentualnym wyborem scenariusza rozwoju w kierunku społeczeństwa wielokulturowego.
\end{abstract}

Słowa kluczowe: wielokulturowość, rozwój zrównoważony, rozwój inteligentny

\section{MULTICULTURALISM AS FACTOR OF SUSTAINABLE AND SMART DEVELOPMENT OF POLAND}

\section{Summary}

The paper addresses the problem of the significance of multiculturalism as a real factor behind sustainable and smart growth of Poland. Multiculturalism is an answer to the question of what the role democracy in the cultural sphere actually consists in.

Generally, the impact of multiculturalism on sustainable and smart development Poland is associated with its expected influence on the formation of a new social and cultural order in society. Multiculturalism tends to promote integration of culturally diverse societies. It creates new forms of desired social cohesion as a necessary factor of economic growth and social development in conditions of a postmodern economy. It removes various forms of cultural predestination, recognises 
the value of minority cultures, which results in their inclusion, thus strengthening the economic power of society. Moreover, multiculturalism creates better conditions for the use of culturally diverse human, social, and cultural capital.

According to the author, Poland is currently solving many dilemmas related to its possible development into a multicultural society.

Key words: multiculturalism, sustainable development, smart growth

JEL: Q56

\section{Wstęp. Znaczenie kultury w rozwoju społeczno-gospodarczym}

W artykule uwagę skupiono na poszukiwaniu odpowiedzi na pytanie, jaka jest rola (znaczenie) wielokulturowości jako realnego czynnika zrównoważonego i inteligentnego rozwoju Polski.

Szeroka perspektywa teoretyczna pracy obejmuje relacje pomiędzy ekonomia a kultura. Przyjęto założenie o narastającym wpływie kultury na zjawiska i procesy ekonomiczne, gospodarcze, a zróżnicowany charakter wpływu w zasadniczej mierze wynika z różnorodności poszczególnych kultur w obrębie badanych krajów oraz ze zróżnicowanego znaczenia, jakie doświadczana wielokulturowość odgrywa w świadomości badanych społeczności.

Rozwinięcie teoretyczne tematu można znaleźć w klasycznej już pracy Lawrence’a E. Harrisona oraz Samuela P. Huntingtona, w której autorzy skoncentrowali się na tym w jaki sposób kultura wplywa na rozwoój społeczeństwa [Harrison, Huntington, 2003, s. 14]. Wielość definicji i stanowisk teoretycznych związanych z pojęciem kultury zdecydowała o odwołaniu się jeszcze do stanowiska wcześniej wspomnianych autorów w zakresie rozumienia kultury jako zmiennej niezależnej stosowanej w badaniach nad relacjami pomiędzy kultura a gospodarką. Przywołani autorzy zdefiniowali kulturę w perspektywie przedmiotowej jako: wartości, postany, przeleonania, opinie oraz leżace u ich podstaw pręeswiadczenia pouszzecbne wśród cztonkón danej spotecżności [Harrison, Huntington, 2003, s. 14].

Chcąc zbadać wpływ określonej kultury na rozwój gospodarczy, należałoby szczegółowiej przeanalizować sfery wartości, postaw i przekonań jako sprzyjających lub niesprzyjających rozwojowi gospodarczemu danego społeczeństwa. Niektórzy autorzy konkretniej wskazali na te czynniki kulturowe, które powinny zostać poddane badaniom pod względem ich wpływu na rozwój gospodarczy [Harrison, Huntington, 2003, s. 105-113]. Zdaniem Mariano Grondona, o rozwoju lub zacofaniu społeczeństwa decydują takie czynniki kulturowe, jak: religia, zbawienie, wiara w jednostkę, stosunek do bogactwa, konkurencji, sprawiedliwości, pracy jako wartości, herezji, edukacji, użyteczności, czasu, racjonalności, władzy, światopoglądu, demokracji [Harrison, Huntington, 2003, s. 105- 113].

Raczej nie rozważa się wpływu kultury jako takiej, ale oddziaływanie konkretnych kultur, które dzięki zawartym tam wartościom i postawom mają wyraźny wpływ na rozwój gospodarczy. 
Ze względu na temat artykułu szczególne ważne byłoby przedstawienie zależności pomiędzy homogeniczną kulturą narodową a rozwojem gospodarczym w porównaniu ze społeczeństwem wielokulturowym, którego cechą charakterystyczną byłyby heterogeniczne, wzajemnie powiązane kultury, a także występującym tam rozwojem gospodarczym.

W badaniach stwierdza się z coraz wyższym stopniem pewności, że zjawisko politycznej mobilizacji opartej jedynie na jednej identyfikacji etnicznej i narodowej rzadko określa wzrost i intensywność zmian społecznych. Raczej następuje proces odwrotny, który powoduje zmiany w kierunku tworzenia się silnych, tradycyjnych aspektów społecznych i kulturowych tożsamości, szczególnie za sprawą ich związku z danym dziedzictwem historycznym, kulturowym, religią i innymi, co bardziej przyczynia się do petryfikacji tradycyjnych sposobów gospodarowania. Wskazują na to zwłaszcza badania nad pograniczami i transgraniczami [Donnan, Wilson, 2007, s. 15-38]. Mobilizacja społeczna oparta na jednym rodzaju identyfikacji de facto blokuje lub ogranicza dostęp do mechanizmów rozwojowych innym jednostkom i zbiorowościom zakorzenionym w odmiennych kulturach, między innymi wywołuje ich marginalizację, poczucie mniejszej wartości, minimalizuje innowacyjność itp. Przykładowo w warunkach polskich interesujące byłoby poszukiwanie odpowiedzi na pytanie, jakie straty (lub korzyści?) poniosła polska gospodarka w wyniku zrealizowanego przez nazistów i warunki wojenne niemal całkowitego ludobójstwa, czystki etnicznej obywateli polskich narodowości żydowskiej na obszarze naszego kraju w czasach drugiej wojny światowej oraz przymusu emigracji mniejszości narodowych, jaki jeszcze miał miejsce w Polsce w pierwszych latach powojennych, a w przypadku mniejszości żydowskiej, także po 1968 roku? Z kolei, jakich korzyści doświadcza polska gospodarka z tytułu sukcesywnego otwierania się na innych, odmiennych kulturowo, a jakich w następstwie imigracji politycznej i zarobkowej setek tysięcy Ukraińców do naszego kraju? Jak dotąd, badania tego typu nie były realizowane.

Wskazania na kulturowe uwarunkowania rozwoju gospodarczego, funkcjonowania organizacji i inne znalazły już swoje miejsce w wielu podręcznikach z zakresu teorii organizacji i zarządzania [Griffin, 1997, s. 704-728; Stoner, Freeman, Gilbert, 2011, s. 185-211]. Czy wobec tego należałoby przyjąć hipotezę, że w dotychczasowej literaturze przedstawiono już wszystkie znane przypadki zależności pomiędzy kulturą a rozwojem społeczno-gospodarczym i mijają się z celem nowe badania? Naturalnie nie. W referacie ustosunkowano się przynajmniej do kilku hipotez, które, zdaniem autora, nieustannie maja nowy charakter $\mathrm{w}$ naukach społecznych $\mathrm{i}$ ich zainteresowaniach gospodarka, a mianowicie:

- brak oczekiwanych związków pomiędzy wielokulturowością a rozwojem społeczno-gospodarczym wynika z braku wiedzy teoretycznej na temat wielokulturowości, z jej upolitycznienia, a w praktyce również z braku: wiedzy stosowanej, umiejętności, programów i woli do konstruowania społeczeństwa wielokulturowego, tak w wymiarze krajowym, jak i regionalno-lokalnym. W warunkach polskich społeczeństwo wielokulturowe jest raczej pos- 
tulatem dotyczącym realizacji w dłuższej perspektywie, aniżeli zorganizowaną postacią istniejąca obecnie;

- państwa, które skonstruowały społeczeństwa wielokulturowe (m.in.: Kanada, Australia), lepiej radzą sobie z rozwojem w porównaniu z etnicznymi państwami narodowymi;

- wielokulturowość wdrażana do praktyki życia zbiorowego raczej wprost nie sprzyja rozwojowi gospodarczemu, niejako za wszelką cenę, ale służy rozwojowi jakościowemu społeczeństwa opartego na wartościach demokratycznych;

- $\quad$ społeczeństwa wielokulturowe są lepiej dopasowane, bardziej adekwatne w stosunku do zrównoważonego, a tym bardziej do inteligentnego rozwoju kraju.

\section{Wielokulturowość, rozwój zrównoważony, rozwój inteligentny}

W tytule artykułu pojawiły się przynajmniej trzy pojęcia wymagające przybliżenia i konkretyzacji, aby była możliwa odpowiedź na pytanie o związek pomiędzy wielokulturowością a zrównoważonym i inteligentnym rozwojem Polski. Uwaga została skupiona jedynie na dookreśleniu kategorii wielokulturowości, ponieważ wokół pojęcia wielokulturowości narosło najwięcej kontrowersji w naukach społecznych i humanistycznych. Występuje ono w wielu znaczeniach zarówno w obiegu naukowym, publicystycznym, jak i politycznym, a zaś pozostałe kategorie autor wykorzystał w typowym rozumieniu, jakie nadały mu nauki ekonomiczne, bez szczegółowych interpretacji teoretycznych.

W literaturze kategoria wielokulturowości jest lub może być traktowana jako: teoria, ideologia, doktryna, program, polityka, wartość, ruch społeczny itp.

Pomijając spory, debaty, jakie przynajmniej od czterdziestu paru lat sa prowadzone w odniesieniu do wielokulturowości, to najogólniej termin ten zakorzenił się w warunkach kształtowania się społeczeństw złożonych z imigrantów. Rzecz dotyczy takich społeczeństw, jak: kanadyjskie, australijskie czy społeczeństwo amerykańskie. Jednocześnie kategoria uformowana w warunkach krajów imigracyjnych, których cecha podstawową jest brak narodu tubylczego, pierwotnego, dominującego, w kolejnych latach została na ogół bezkrytycznie przeniesiona do warunków krajów europejskich. Natomiast jedną z podstawowych cech strukturalnych jest istnienie w danych państwach narodów dominujących, ukształtowanych w dłuższej perspektywie historycznej, a także występujących tam równocześnie mniejszości narodowych, etnicznych, zbiorowości regionalnych, lokalnych i innych, których bliższe poznanie wymaga odwołania się do konkretnych badań.

Od początku zorganizowania się poszczególnych narodów europejskich w państwa na ogół była prowadzona polityka asymilacji, naturalizacji z zamiarem inkorporacji czy po prostu wchłonięcia równolegle zamieszkujących tam od dawna mniejszości narodowych i etnicznych, jak również przybywających coraz częściej cudzoziemców z innych 
krajów. Dopiero po niepowodzeniu, upadku polityki asymilacji, naturalizacji osób i zbiorowości odrębnych kulturowo kształtowała się polityka integracji oparta na takich wartościach, jak: tolerancja, prawa człowieka do zachowania własnej kultury i wolności wyboru różnych form przynależności grupowej.

Warto podkreślić, że procesy, ogólnie określane jako wielokulturowe, nie sposób badać za pomoca jednego pojęcia ani jednej metodologii, ponieważ w praktyce poszczególne kraje zdobywają rozmaite doświadczenia zarówno w zakresie realizacji polityki wielokulturowości, jak i różnych działań pragmatycznych w odniesieniu do osób i zbiorowości odmiennych kulturowo. Są to przecież różnorodne podmioty tej polityki. Innej polityki wymagaja przybysze o ukształtowanej tożsamości narodowej, a innej przybysze o tożsamości narodowej in statu nascendi. Innej polityki wymagają przybysze z podobnych kręgów kulturowych, z tej samej cywilizacji, a innej przybysze $z$ innych cywilizacji. Tak naprawdę dramatyczne problemy związane $z$ wielokulturowością pojawiły się dopiero w warunkach, kiedy imigrowali przybysze z obszarów odmiennych cywilizacyjnie, z zasadniczo odmiennymi oczekiwaniami, potrzebami, z odmiennymi wizjami: świata, człowieka, rodziny, szczęścia, sukcesu, przybysze wyposażeni w zasadniczo odmienne wzorce kulturowe, gdy ich oczekiwania wyraźnie lub zdecydowanie rozmijały się z oczekiwaniami przyjmujących ich narodów zorganizowanych w państwa.

W literaturze wielokulturowość ma przynajmniej kilka znaczeń. Najbardziej rozpowszechniona jest definicja wielokulturowości jako realnie występującego zróżnicowania kulturowego. Przykładowo Marian Golka postrzegał wielokulturowość jako: wspótwystępowanie na tej samej przestrzeni (albo w bezpośrednim sasiedztwie bez wyraźnego rozgraniczenia albo w sytuacji aspiracii do zajecia tej samej przestrzeni) dwóch lub wiecej grup społecznych o odmiennych cechach dystynk.tywnych: wygladzie zewnetrznym, jezyk.u, wyznaniu religijnym, uktadzie wartości itp., które prayczyniaja sie do wajemnego postraegania odmienności z. różnymi tego skutkami [Kempny, Kapciak, Łodziński, 1997, s. 54].

Jednocześnie przez wielokulturowość rozumie się obiektywy i narastający proces społeczny i kulturowy związany z procesami: interakcji, przenikania lub nakładania się kultur [Kempny, Kapciak, Lodziński, 1997, s. 64].

Często wielokulturowość jest traktowana zamiennie jako synonim międzykulturowości, multikulturalizmu, transkulturowosci itp. W nawiązaniu do C. Taylora, Joanna Kurczewska wyróżniła multikulturalizm łagodny jako wyraz: potrzeby szacunku i uгnania dla jednostek i grup dyskryminowanych w obecnym uktadzie żcia publicznego demokracji liberalnych i twardy „mocny” będący: waględnie spójnq doktryna emancypacïi politycznej dyskryminowanych grup kulturowych, których członkowie, uważajac swoje kultury za autentyczne i odręne od innych, roszcza sobie prawo do zrównani siebie $i$ swoich kultur z. kultura dominujaca w sferze publicznej [Kempny, Kapciak, Łodziński, 1997, s. 49].

Wreszcie przez wielokulturowość rozumie się zasadę demokratycznego współżycia w jednym państwie różnych grup kulturowych. Według M. Kempnego, A. Kapciaka i S. Lodzińskiego, wielokulturowość jest to: zasada demokratycznego wspótistnienia jednostek i grup powotujacych się na swoja szczególna to ̇̇samość kulturowa [Kempny, Kapciak, Lodziński, 1997, s. 8-9]. 
W literaturze amerykańskiej multikulturalizm często jest traktowany jako odpowiedź na dyskryminację i zróżnicowanie kulturowe. Występuje w niej odrzucenie asymilacji i melting potu jako sposobów narzucania kultury dominującej, jak również przekonanie, że wszystkie grupy kulturowe powinny zostać rozpoznane, uwzględnione i respektowane, opowiadanie się za tym, aby to zróżnicowanie kulturowe było podtrzymywane nie tylko przez rodziny i struktury nieformalne (społeczności lokalne, szkoły etniczne, religijne), ale także przez świeckie szkoły publiczne. Rzecz w tym, by budować społeczeństwa bez uprzedzeń i dyskryminacji [Glazer, 1997].

Wobec nowych wyzwań, jakie przeżywa Europa, powodowanymi masowymi migracjami do Europy uciekinierów z obszarów objętych konfliktami zbrojnymi, ale także migrantów ekonomicznych z krajów Afryki, Bliskiego Wschodu i innych pojawiły się nowe interpretacje wielokulturowości dotyczące przystosowania imigrantów do pracy i życia w warunkach europejskich. Tariq Modood stwierdził, że pod pojeciem multikulturalizmu rozumié́ bede tutaj polityczna akomodacje mniejszości, które uytonity sie za sprawa migraiji do krajón zachodnich spoza obszaru bogatego Zachodu. [Modood, 2014, s. 17].

Przytoczono kilka stanowisk w sprawie rozumienia terminu wielokulturowość, aby skonstatować, że w literaturze przedmiotu kategoria ta nie jest definiowana jednoznacznie i wymaga dopracowania, a w badaniach przyjęcia określonego stanowiska. Wielokulturowość jest stosowana do oznaczenia istniejącego realnie zróżnicowania kulturowego społeczeństwa, bez względu na stan jakościowy tego zróżnicowania lub będąc traktowana jako proces służy wyznaczeniu kierunku przemian ku przenikaniu bądź nakładaniu się kultur. Wreszcie jest stosowana do oznaczenia zasadniczo nowego ładu kulturowego w społeczeństwie, cechującego się zasadą demokratycznego współżycia społeczności wyposażonych w różne kultury albo do ustalenia nowego społeczeństwa pozbawionego dyskryminacji i uprzedzeń etniczno-narodowych, szerzej grupowych.

Wykorzystuje się definicje deskryptywne, opisujące stan istniejący oraz definicje normatywne określające wizje społeczeństwa wielokulturowego jako społeczeństwa przyszłego, które w procesach przeobrażeń rozwiązuje lub rozwiązało szereg problemów i zagrożeń związanych ze współżyciem międzykulturowym. W związku z tym, krótko przedstawiono stanowisko autora w sprawie wielokulturowości.

Autor przez wielokulturowość rozumie dynamiczne, zinstytucjonalizowane na zasadach demokratycznych oraz zintegrowane współżycie w obrębie: państwa jednostek, wspólnot $\mathrm{i}$ innych form zbiorowości społecznych cechujących się wyartykułowaną społecznie tożsamością kulturową.

W definicji zakładano, że samo współwystępowanie na określonej przestrzeni dwóch lub więcej grup, kategorii kulturowych nie oznacza istnienia wielokulturowości. Wówczas mamy do czynienia co najwyżej ze zróżnicowaniem kulturowym. To natomiast jest pierwszym etapem kształtowania się demokracji w sferze kulturowej. Aby mogło ono zaistnieć, powinny zostać wprowadzone elementarne zasady tolerancji kulturowej. Zróżnicowanie kulturowe oznacza, że grupy i kategorie kulturowe uzyskały prawna możliwość legalnego i swobodnego funkcjonowania. Na tym etapie istnieje stratyfikacja i nierzadko dyskryminacja kulturowa, ale poszczególne mniejszości w procesie swo- 
jego upodmiotowienia mają możliwości sprzeciwu i troski o własny rozwój kulturowy.

Zróżnicowanie kulturowe, obok zjawisk wartościowanych pozytywnie, jest przyczyną wielu problemów, których rozwiązywanie może prowadzić do etapu pluralizmu kulturowego, natomiast ten traktuje się jako etap pośredni pomiędzy zróżnicowaniem kulturowym a wielokulturowością. Za R. Luhmanem i S. Gilmanem można powiedzieć, że pluralizm kulturowy służy określeniu społecznego jego ładu, jak również stwarza warunki do partnerskiego rozwoju (wolność i równość kultur mniejszościowych) w połączeniu z wysiłkiem mniejszościowych grup kulturowych w kierunku rozwijania własnych kultur [Luhman, Gilman, 1980, s. 145-147].

Zdaniem autora, z fenomenem wielokulturowości mamy do czynienia dopiero wówczas, gdy dochodzi do trwałych, wielopłaszczyznowych i dobrowolnych kontaktów międzykulturowych, które powodują wytworzenie się całości jakościowo nowej i kulturowo zróżnicowanej. W przypadku Europy, a tym bardziej Polski, jest to perspektywa, która może zostać zrealizowana, ale wcale nie musi. Według tego stanowiska, krajami o zaawansowanej integracji międzykulturowej, które można określić jako społeczeństwa wielokulturowe, są m.in.: Australia, Nowa Zelandia, Kanada [Modood, 2014, s. 15], a w warunkach europejskich niewatpliwie Szwajcaria. Wprawdzie trudno ustalać wskaźniki szczegółowe, lecz jest możliwe wyznaczenie przynajmniej kilku. Na etapie wielokulturowości jako modelu mamy do czynienia z kresem dominacji kulturowej, kresem nadrzędnej pozycji dotychczasowej grupy dominującej i jej kultury w stosunku do pozostałych. W procesach integracyjnych nie tylko przybysze lub mniejszości dostosowują się do rdzenia większościowego, ale jednocześnie większości, pozbawione predystynowanego wsparcia państwowego, przystosowują się do innych. Natomiast społeczeństwo uzyskało taki stopień integracji wewnętrznej, że jest zdolne do osiagania zamierzonych celów, wykorzystując przy tym zróżnicowanie kulturowe. Jest to więc etap, na którym społeczeństwo nie ma wątpliwości, że zróżnicowanie kulturowe jest korzystne wobec całego społeczeństwa. Państwo staje się organizacją polityczną całego społeczeństwa, a nie tylko grupy dominującej, a jego struktura i funkcjonowanie odzwierciedla realne zróżnicowanie kulturowe społeczeństwa.

Przedstawiony skrótowo model społeczeństwa wielokulturowego można odnieść do najogólniejszej formy odpowiedzi na pytanie, na czym ma polegać demokracja w sferze kulturowej. Proces konstruowania społeczeństwa wielokulturowego w warunkach poszczególnych krajów powinien przebiegać poprzez wprowadzanie i poszerzanie zasad demokratycznych w przestrzeni kulturowej, a mianowicie zasad: równości, wolności i sprawiedliwości z odpowiednią ich interpretacją. Gwarantem wdrażania koncepcji wielokulturowości są system demokratyczny, instytucje i organizacje pozarządowe, wprowadzanie zasad tolerancji, edukacji międzykulturowej, a może przede wszystkim doświadczanie korzyści z tytułu międzykulturowego współżycia.

W opinii autora, dopiero tak zdefiniowana wielokulturowość może być traktowana jako zmienna niezależna do badania jej wpływu na zrównoważony $\mathrm{i}$ inteligentny rozwój danego kraju, w tym także Polski. W obecnych warunkach Rzeczypospolitej by- 
łoby to co najwyżej tworzenie podstaw teoretycznych do przeprowadzenia przyszłych badań.

Wśród badaczy zjawisk i procesów związanych ze zrównoważonym rozwojem dominuje definicja sformułowana w 1987 roku w Raporcie Światowej Komisji Środowiska i Rozwoju jako: proces majacy na celu zaspokojenie aspiracji rozwojonych obecnego pokolenia, w sposób umo:̇liwiajacy realizacje tych samych dażen nastepnym pokoleniom.

Nie ulega wątpliwości, że realizacja idei zrównoważonego rozwoju ściśle wiąże się $z$ realizacja postulatu wielokulturowego społeczeństwa. Zgodnie z kategoria (modelem) zrównoważonego rozwoju, rozwój ma zapewnić zaspokojenie aspiracji społecznych, ekonomicznych obecnemu i następnym pokoleniom, a więc zakłada transmisję kompleksowych osiagnięć ekonomiczno-społecznych z pokolenia na pokolenie. Może to mieć miejsce jedynie w społeczeństwie, w którym wypracowano nowe formy społecznej spójności i zaufania, zasadniczo wykraczające poza tradycyjne więzi: narodowe, religijne czy terytorialne, natomiast priorytetem jest nie wasko rozumiany rozwój gospodarczy, ale społeczno-ekonomiczny, ekologiczny i kulturowy rozwój człowieka. Rozwój zrównoważony jest bliski kategorii rozwoju endogennego, który służy aktywności całych społeczności terytorialnych, mobilizując czynniki i potencjał ukryty lub mniej widoczny z makrospołecznego punktu widzenia. Każda kultura bowiem jest bardzo blisko związana z terytorium: lokalnym, regionalnym, narodowym, co sprzyja ochronie zasobów naturalnych środowiska przyrodniczego. Naturalnie, poza ochrona różnorodności przyrodniczej, rozwój zrównoważony zakłada także ochronę i rozwój różnorodności kulturowej, a to obok autotelicznej wartości w postaci ochrony poszczególnych kultur, zwrotnie stanowi równocześnie autonomiczny czynnik rozwojowy.

Rozwój zrównoważony zakłada włączenie do zadań rozwojowych całego zróżnicowanego kulturowo społeczeństwa i jest to typ rozwoju inkluzyjnego, a nie ekskluzywnego. Zarówno poszczególne jednostki, jak i zbiorowości zróżnicowane kulturowo wnoszą do społeczeństwa swoje potencjały rozwojowe. Jednakże ukształtowane społeczeństwa wielokulturowe niewatpliwie wnoszą nowe dodatkowe czynniki powodujące przewagi konkurencyjne w stosunku do innych. Jak dotychczas, bliższych argumentów tego typu moga dostarczyć doświadczenia rozwojowe jedynie takich krajów, jak: Kanada, Australia, Stany Zjednoczone, a w części nawet Wielka Brytania.

W przekonaniu autora, najmniej doprecyzowaną naukowo kategorią jest rozwój inteligentny. Przede wszystkim Program Operacyjny Inteligentny Rozwój został określony przez Ministerstwo Rozwoju Regionalnego jako nowa perspektywa finansowa przewidziana na lata 2014-2020 [Inteligentny rozwój..., 2014]. Wiąże się on z: rozwojem innowacyjności przedsiębiorstw, konstruowaniem powiązań pomiędzy instytucjami naukowymi i przedsiębiorstwami, ze wzmocnieniem jakości badań i pozycji krajowych jednostek naukowych w europejskiej przestrzeni badawczej itp. Kategoria wymaga jeszcze bliższych studiów teoretycznych, jednak jest zrozumiała nawet intuicyjnie. Chodzi o preferowanie rozwoju poprzez: innowacje, wynalazki i powiazanie nauki z rozwojem gospodarczym.

W związku z powyższym, można stwierdzić, że główne światowe ośrodki badawczo-rozwojowe stanowią instytucje i organizacje wielokulturowe. Zdaniem Fareeda 
Zakarii: amerykanski, ukryty selkret polega na tym, ze wiekszośc tych insisynierón sq imigrantami. Studenci zagraniczni i imigranci licza prawie 50\% pracownikón naukonych w kraju (...). Niemal potowa wszystkich pracowników w Dolinie Krzemowej to imigranci w pierwssym pokoleniu. Potencjat nowego prazyspieszenia amerykańskiej produktywności zalesy nie od sytemu edukacyjnego lub Re D wydatkón na badania i rozwój, ale od polityki imigracyjnej (...). Jest to sita Ameryki. Spoteczeństwo otwarte, elastycżne, zdolne do absorpcji innych ludzi, ich kultur, idei, dóbr, ustug [Zakaria, 2008].

\section{Wielokulturowość jako przedmiot krytyki}

Obecnie wielokulturowość stała się przedmiotem krytyki ze strony: wielu polityków, środowisk narodowych i religijnych. Zdaniem autora artykułu, najogólniej wynika ona $\mathrm{z}$ traktowania wielokulturowości w sposób populistyczny, a nie naukowy, jako teorii rozwoju społeczeństw zróżnicowanych kulturowo, jak również z nadzwyczajnego upolitycznienia pojęcia przez łączenie wdrażania idei wielokulturowości z rządzeniem elit centrolewicowych i lewicowych, które obecnie znajdują się w odwrocie w całej Europie. Co więcej, stanowi wyraz braku wiedzy o miejscu narodu, religii, szerzej kultury, w świecie ponowoczesnym, świecie zrównoważonego i inteligentnego rozwoju.

W związku z tym, że kierunki krytyki wielokulturowości autor przedstawił w innych publikacjach [Biernacka, Krzysztofek, Sadowski, 2012, s. 11-36], w artykule tym wskazano przynajmniej kilka argumentów przemawiających za tym, że, niezależnie od wielości stanowisk krytycznych, społeczeństwa wielokulturowe są i będą bardzo atrakcyjną wiedza, propozycją badawcza, i pożądanymi kierunkami realizacji określonych polityk wielokulturowości. Pozwola one nie tylko uzyskiwać przewagi konkurencyjne, ale także kształtować nowe typy człowieka demokratycznego, otwartego na innych. W modelu społeczeństwa wielokulturowego mamy do czynienia z upodmiotowieniem mniejszości: narodowych, etnicznych, religijnych, regionalnych, ekonomicznych, płciowych i innych dotąd zmarginalizowanych lub niedowartościowanych, mających poczucie deprywacji w dotychczasowych społeczeństwach.

Nie sposób zahamować złożonych procesów imigracyjnych, których przedstawiciele, w przeciwieństwie do czasów minionych, nie są najczęściej zorientowani na procesy asymilacyjne, lecz na konstruowanie lepszego życia w nowych miejscach zamieszkania, na ogół bez rezygnacji z kultur własnych. Wobec tego jest i będzie istniała potrzeba podjęcia złożonych działań na rzecz ich integracji w nowych warunkach demokratycznych.

Jeżeli będą zachowane utrzymujące się zróżnicowania kulturowe, to konieczne staną się poszukiwania nowych form spójności społecznej i kulturowej jako czynników społecznego ładu oraz ważnych czynników wzrostu gospodarczego i społecznego rozwoju. Niezależnie od tego, że przynajmniej w warunkach europejskich, polskich, w przekonaniu autora, kształtuje się nowy etap rozwoju tożsamości narodowych, m.in. w postaci troski o najlepsze miejsce swojego narodu wśród różnych form interakcji i integracji ponadnarodowych, co ogranicza procesy tworzenia się społe- 
czeństw wielokulturowych, to jednak idea państwa narodowego w dłuższej perspektywie ulegnie wyczerpaniu. Powstaje pytanie, jakie nowe formy integracji ponadnarodowej mamy do zaoferowania poszczególnym społeczeństwom? Prawdopodobnie dokonają się one w ramach poszczególnych państw, a nie pomiędzy nimi, to natomiast skłania do rozważań i wdrażania właśnie różnych koncepcji wielokulturowości.

\section{Różnorodność zinstytucjonalizowana w warunkach demokratycznych a rozwój zrównoważony}

Najogólniej, wpływ wielokulturowości na zrównoważony i inteligentny rozwój Polski autor wiąze z oczekiwanym jej wpływem na kształtowanie się nowego ładu społeczno-kulturowego w społeczeństwie. Nie chodzi tutaj o jakiś nowy ustrój polityczny, ale o takie przemiany demokratyczne, w wyniku których wszystkie występujące w społeczeństwie zbiorowości kulturowe będą widoczne, obecne oraz będą włączone do mechanizmu rozwojowego. Byłby to taki typ nowego ładu, w którym brak jest społecznego wykluczenia, a dzięki zjawiskom włączania wielość występujących zbiorowości uzyskałyby satysfakcje z tytułu aktywności na rzecz społecznego rozwoju. W praktyce, zjawisko wielokulturowości usuwa ze stosunków międzyludzkich różne formy predestynacji kulturowej, dowartościowuje kultury mniejszościowe, co powoduje ich włączanie, a więc umacnia przez to siłę ekonomiczną społeczeństwa. Procesy włączania innych, odmiennych kulturowo do mechanizmów rozwojowych służą powiązaniu rozwoju gospodarczego z wielością wartości, wzorów zachowań, zaś to zasadniczo wzbogaca koncepcje i realizacje procesów rozwojowych.

Warto nawiązać do podstawowych czynników rozwojowych, które prowadzą do zbudowania społeczeństwa kreatywnego, natomiast jego koncepcja jest bliska społeczeństwu wielokulturowemu. Zdaniem R. Floridy, koncepcje wzrostu gospodarczego powinny być oparte na trzech podstawowych czynnikach, takich jak: technologia, talent i tolerancja. Z punktu widzenia wpływu wielokulturowości na rozwój zrównoważony ważne jest bliższe zainteresowanie czynnikiem tolerancji. Według R. Floridy, na czynnik tolerancji składają się cztery segmenty, a mianowicie: Gay Index (liczebność gejów), Bohemian Index (liczebność i różnorodność klasy kreatywnej), Melting Pot Index (wskaźnik tygla narodów) oraz miernik integracji rasowej (stopień integracji społeczności zróżnicowanej rasowo) [Florida, 2010, s. 14-15]. Duże zainteresowanie wzbudza, szczególnie podkreślany, związek między wysoką koncentracją gejów a wzrostem gospodarczym. Po prostu zwiększona obecność gejów w środowisku świadczy o wysokim stopniu otwartości na innych i o istnieniu kultury wolnej od uprzedzeń i stereotypón, a więc sprazyjajacej keatywności [Florida, 2010, s. 13].

Uogólniając, w następstwie masowych migracji: ekonomicznych, socjalnych, politycznych w poszczególnych krajach, tzw. siła robocza staje się zróżnicowana kulturowo. Poszczególne przedsiębiorstwa z konieczności lub z wyboru już korzystają i będa korzystać ze zróżnicowanego kulturowo potencjału ludzkiego. Wówczas umiejętność zarządzania wielokulturowymi zespołami pracowniczymi stanie się znaczącym czynni- 
kiem przewagi konkurencyjnej i powodzenia organizacji. Obecnie w podręcznikach dotyczących zarządzania ukazuje się korzyści z tytułu umiejętnego zarządzania organizacją wielokulturowa. Autorzy nawiązywali m.in. do stanowiska Taylora Coxa, który przedstawił sześć argumentów przemawiających za sprawnym zarządzaniem organizacją wielokulturowa. Autor wskazał na: argument kosztowy, argument dotyczący pozyskania zasobów ludzkich, argument rynkowy związany z twórczością i rozwiązywaniem problemów oraz argument obejmujący elastyczność systemu [Stoner, Freeman, Gilbert, 2011, s. 205-207].

Najogólniej wielokulturowość będzie sprzyjać integracji społeczeństwa zróżnicowanego kulturowo. Stworzy przesłanki do nowej formy pożądanej spójności społecznej jako koniecznego czynnika wzrostu gospodarczego i społecznego rozwoju w warunkach ponowoczesnej gospodarki. W warunkach utraty znaczenia takich podstawowych więzi integracyjnych, jak: narodowe, religijne, terytorialne, lokalne, ukształtowana wielokulturowość wytworzy nowe, które połączą mieszkańców zróżnicowanych kulturowo. Autor ma na myśli: szacunek dla odmiennych tożsamości, postawy zainteresowania odmiennością, orientację na pracę, kreatywność, poczucie bezpieczeństwa. Są to wartości, które w sposób żywiołowy raczej nie powstaną lub mogą się kształtować w dłuższym okresie. Celowe przygotowanie się do nowych warunków rozwojowych powinno łączyć się z podjęciem masowej edukacji kulturowej, w tym zwłaszcza międzykulturowej, aby zapoznać społeczeństwo ze zróżnicowaniem kulturowym współczesnego świata, poszczególnych krajów, regionów.

Autor opowiada się za tym, żeby edukację międzykulturową traktować jako edukację o: zróżnicowaniu kulturowym społeczeństwa bądź jego poszczególnych segmentów, umiejętności międzykulturowego współżycia, rozwiązywaniu związanych z tym problemów oraz systematycznym poszukiwaniu wszelakich korzyści, jakie może odnieść społeczeństwo jako całość z faktu zróżnicowania kulturowego mieszkańców i z nabywania przez obywateli kompetencji do życia w społeczeństwie pluralistycznym. W opinii autora, podstawowym zadaniem edukacji międzykulturowej jest wspieranie przeobrażeń społeczeństwa zróżnicowanego kulturowo w kierunku społeczeństwa pluralistycznego.

Nawet, pomijając złożone (społecznie potrzebne) debaty na temat istoty edukacji międzykulturowej, to w jej obrębie powinny znaleźć się: wartości podstawowe; konkretna wiedza na temat zróżnicowania kulturowego danego społeczeństwa i świata; różne zdobyte i postulowane doświadczenia na temat: wzorów, mechanizmów i zasad międzykulturowego współżycia; nabywanie kompetencji dotyczących realizacji kontaktów oraz międzykulturowego współżycia z innymi ludźmi spoza naszego kodu kulturowego; kształtowanie postaw, w tym szczególnie zrozumienie oraz szacunek dla innych (relatywizm kulturowy), ich wartości i postaw w ostatniej instancji kształtowanie osobowości pluralistycznej, szeroko otwartej na inne zbiorowości i ich kultury.

Odpowiednio wyposażone w wiedzę, postawy otwartości i umiejętności nawiązywania kontaktów z innymi społeczeństwo stanie się bardziej odporne na stany lękowe, a jego członkowie będą czuć się bezpieczniej w kontaktach międzykulturowych. 
Przykładowo, czy znane jest mieszkańcom rzeczywiste zróżnicowanie kulturowe województwa podlaskiego? W świetle dotychczasowej wiedzy, przede wszystkim na użytek dydaktyczny, warto zaprezentować realnie istniejącą strukturę etniczno-kulturową mieszkańców województwa podlaskiego. Mianowicie, obok Polaków jako: historycznej, narodowej, wyznaniowej i terytorialnej większości, w województwie przebywają:

- mniejszości narodowe: Białorusini, Ukraińcy, Litwini, Rosjanie, Żydzi;

- mniejszości etniczne: Tatarzy i Romowie;

- mniejszości religijno-wyznaniowe: prawosławni, muzułmanie, protestanci, starowiercy, wyznawcy judaizmu i inni;

- $\quad$ zbiorowości subregionalne: mieszkańcy Białostocczyzny (jako kategorii kulturowej, nie zaś administracyjnej), Ziemi Łomżyńskiej i Suwalszczyzny;

- $\quad$ zbiorowości zakorzenione w określonych kulturach pochodzenia (przynależności historycznej), tj.: chłopskiego, poszlacheckiego, akcydentalnie inteligenckiego;

- zbiorowości miejskie, małomiasteczkowe i wiejskie o wyraźnie odrębnym poczuciu tożsamości;

- miejscowi i przybysze;

- nowe kategorie kulturowe: imigranci.

Wyróżniona struktura kulturowa województwa podlaskiego może stanowić etap wyjściowy do konstruowania programu kształtowania społeczeństwa wielokulturowego w wymiarze regionalnym. Wymienione całości nie są homogeniczne kulturowo, nie wykluczają się wzajemnie, a także nie zawsze są wewnętrznie zintegrowane. Jednakże łącznie tworzą dynamiczny, zmienny i często wzajemnie powiązany, a wręcz wymieszany, konglomerat zróżnicowania kulturowego mieszkańców województwa podlaskiego. Czy przedstawione zróżnicowanie kulturowe jest znane mieszkańcom? Nawet jeżeli jest znane, to czy można dostrzec jego obecność w sferze publicznej? Czy ewentualnie wykorzystuje się $\mathrm{w}$ działaniach do uzyskania przewagi konkurencyjnej? Temat ten, jak dotąd, pozostaje otwarty.

\section{Wielokulturowość jako poszerzanie przestrzeni zaufania}

Osiagnięcie wysokiego stopnia integracji społeczeństwa zróżnicowanego kulturowo stworzyłoby lepsze warunki do wykorzystania kapitału: ludzkiego, społecznego i kulturowego. W nawiązaniu do R. Floridy warto zauważyć, że obecnie do wzrostu gospodarczego w krajach wysoko rozwiniętych ekonomicznie szczególnie przyczyniają się klasy kreatywne jako zintegrowane zbiorowości cechujące się: wysokim wykształceniem, różnorodnością społeczno-kulturowa, otwartością i tolerancyjnością wobec innych. Społeczeństwa wielokulturowe będą wytwarzać nowe typy wspólnot, takich, które będa przyciagać przedstawicieli klasy kreatywnej. Zdaniem R. Floridy: ludrie kreatywni szukaja w lokalnej wspólnocie wielu wysokiej jakości doznań, instytucij $i$ udogodnień, otwartości na wszelkiej maści różnorodność i odmienność oraz - przede wssystkim - mo:̨liwości potwierdzenia swojej to:̇samości jako osób kreatymmych [Florida, 2010, s. 224]. W związku z tym, stwarzanie miejsc 
do pracy i życia charakteryzujących się zachowaniem różnorodności: przyrodniczej, społecznej, a także etnicznej, religijnej, rasowej oraz mierzonej innymi wymiarami staje się wręcz podstawą realizacji idei zrównoważonego rozwoju.

W Polsce czyni się wiele wysiłków, aby zintegrować społeczeństwo wokół wartości: patriotycznych, narodowych, religijnych, rzadziej regionalnych i lokalnych. W nawiązaniu do typologii kapitału społecznego R. Putnama są to działania sprzyjające budowaniu kapitału wiążącego, a nie pomostowego. "Wiqżacy» kapitał społeczny - zdaniem R. Putnama - oznacza relacje międyy ludźmi podobnymi do siebie, czyli jest w istocie caynnnkiem wyznaczajacym homogenicznośc danego spoteczeństwa (...). Natomiast "pomostowy» kapitat spoteczny odnosi sie do budowania powiazań miedzy oddalonymi od siebie, heterogenicznymi grupami; «pomostowe» wiezi sq znacznie stabsze, ale takìe znacznie bardziej inkluzywne, pozwalaja przekraczać bariery struktury społecznej i dystans pomiędzy różnymi kategoriami dzielacymi ludri wedtug rasy, płci, wyžnania, zamożności itd. [Trutkowski, Mandes, 2005, s. 62].

Wyzwalanie kapitału społecznego i kulturowego może stać się bardzo istotnym czynnikiem zrównoważonego rozwoju: kraju, regionu i miasta [Sadowski, 2006].

\section{Podsumowanie. Uwarunkowania znaczenia wielokulturowości jako czynnika rozwoju Polski}

Według badań prowadzonych przez autora, obecnie Polska znajduje się na etapie społeczeństwa zróżnicowanego kulturowo, a jednocześnie w warunkach konieczności rozwiązywania wielu dylematów związanych z ewentualnym wyborem scenariusza dalszego rozwoju w kierunku społeczeństwa wielokulturowego.

Generalnie, społeczeństwo polskie jest zintegrowane na następujących zasadach: polityczno-państwowej, narodowej, terytorialnej, językowej, religijnej, a także przymusu polityczno-prawnego. Zasada integracji kulturowej nie obejmuje całego społeczeństwa.

Można antycypować, że społeczeństwo polskie zasadniczo może ulegać przeobrażeniom przynajmniej w dwóch kierunkach. Pierwszym jest dalsze utrwalanie statusu polskiego państwa narodowego ze śladowym udziałem mniejszości narodowych i etnicznych, które będą ulegać kolejnym procesom asymilacyjnym; z trwałymi, silnie zabezpieczonymi militarnie granicami administracyjnymi, ale także z wyrazistymi granicami społecznymi i kulturowymi oddzielajacymi Polaków zwłaszcza od sasiadów wschodnich; z dominacją wyznania rzymskokatolickiego w życiu publicznym, społeczeństwa o przewadze cech ekskluzywnych, relatywnie zamkniętego na innych, przywiązującego szczególną wagę do zachowania swojej suwerenności politycznej i narodowej w warunkach Unii Europejskiej.

Drugim sa przeobrażenia zorientowane na konstruowanie społeczeństwa pluralistycznego. Można wskazać wiele przesłanek, że społeczeństwo polskie zmierza właśnie w kierunku społeczeństwa pluralistycznego. W związku z masowymi wyjazdami zagranicznymi, z intensywną nauką języków obcych, społeczeństwo polskie uczy się innych kultur, nabywa kompetencji międzykulturowych, realizuje się wiele badań 
interkulturowych i programów edukacji międzykulturowej. W Polsce szeroko jest prowadzony dialog międzykulturowy, w tym zwłaszcza dialog międzyreligijny.

Patriotyzm etniczny etapowo zamienia się w polityczny, a nawet konstytucyjny. Następuje także proces konstruowania nowego narodu polskiego jako narodu pluralistycznego i obywatelskiego. Grupy mniejszościowe stopniowo stają się partnerami w społeczeństwie, mają coraz szersze możliwości artykulacji swoich tożsamości społecznych oraz są obecne w życiu publicznym społeczeństwa.

W zakończeniu autor artykułu wyraża przekonanie, że dalsze perspektywiczne przemiany społeczeństwa polskiego w kierunku wielokulturowego, sukcesywnie będą tworzyć konieczną bazę społeczno-kulturową, a więc umacniać postawy i działania zmierzające do realizacji koncepcji zrównoważonego i inteligentnego rozwoju kraju.

\section{Literatura}

Donnan H., Wilson T. M., 2007, Granice tożsamości, narodu, państwa, Wydawnictwo Uniwersytetu Jagiellońskiego, Kraków.

Florida R., 2010, Narodziny klasy kreatywnej, Narodowe Centrum Kultury, Warszawa. Glazer N., 1997, We are All Multiculturalists Now, Harvard University Press, London.

Griffin R. W., 1997, Podstawy zarzqdzania organizacjami, Wydawnictwo Naukowe PWN, Warszawa.

Inteligentny Rozwój Archives / Program Operacyjny Inteligentny Roẓwój (PO IR) - Fundusze Europejskie 2014, http:/ /inteligentny-rozwój.com.pl/index.php/tag/inteligentnyrozwój/g.21,38 (data wejścia: 29.06.2016).

Kempny M., Kapciak A., Lodziński S., 1997, U progu wielokulturowości. Nowe oblicza spoleczeństwa polskiego, Oficyna Naukowa, Warszawa.

Kultura ma znaczenie, 2003, L. E. Harrison, S. P. Huntington (red.), Wydawnictwo Zysk i S-ka, Poznań.

Luhman R., Gilman S., 1980, Race and Ethnic Relations, Belmont, California.

Modood T., 2014, Multikulturalizm, Wydawnictwo Nauka i Innowacje, Poznań.

Putnam R., 1995, Demokracja w dziataniu: tradycje obywatelskie we wspótczesnych W toszech, Instytut Wydawniczy „Znak”, Kraków-Warszawa.

Sadowski A., 2006, Białystok. Kapitat społeczny mieszkańcón miasta, Wydawnictwo Wyższej Szkoły Ekonomicznej w Białymstoku, Białystok.

Społeczensstwo wielokulturowe - nowe wyzwania i zagrożenia, 2012, M. Biernacka, K. Krzysztofek, A. Sadowski (red.) Wydawnictwo Uniwersytetu w Białymstoku, Białystok.

Stoner J. A. F., Freeman R. E.,. Gilbert D. R. Jr., 2011, Kierowanie, Polskie Wydawnictwo Ekonomiczne, Warszawa.

Trutkowski C., Mandes S., 2005, Kapitat spoteczny w matych miastach, Wydawnictwo Naukowe SCHOLAR, Warszawa.

Zakaria F., 2008, The Rice of the Rest, [za:] The Post American World, „Newsweek”, z 12 maja. 